\title{
JENIS LAYANAN BK
}

\section{(LANJUTAN)}

\author{
Khairunnisa Syafrita (19029153) \\ Universitas Negeri Padang \\ Email : khairunissasyafrita@gmail.com
}

\begin{abstract}
Counseling is assistance given to individuals to be independent by using a variety of materials, interactions, advice and ideas in a nurturing atmosphere, based on prevailing norms. Counseling services are provided to help individuals who are facing problems in their life. The counselor and the client must create a relationship during the counseling process so that the individual can be independent. Where individuals are able to make their own decisions
\end{abstract}

Keywords: counseling, individual, services.

\section{PENDAHULUAN}

Bimbingan dan konseling adalah pelayanan bantuan untuk peserta didik, baik secara perorangan maupun kelompok, agar mampu mandiri dan berkembang secara optimal, dalam bidang bimbingan belajar dan bimbingan karir, melalui berbagai jenis kegiatan pendukung, berdasarkan norma-norma yang berlaku.

Guru BK memiliki berbagai alat untuk mengembangkan potensi yang ada dalam diri peserta didik. Wujud nyatanya adalah dengan memberikan layanan-layanan yang ada dalam bimbingan konseling, seperti layanan orientasi, layanan informasi, layanan penempatan dan 
penyaluran, layanan konseling individu, layanan konseling kelompok, layanan bimbingan kelompok, layanan penguasaan konten, layanan mediasi, layanan konsultasi, dan layanan advokasi.

Tujuan Penelitian

Penelitian ini bertujuan untuk mengetahui jenis layanan bimbingan konseling.

Metode Penelitian

Metode penelitian ini menggunakan metode penelitian tinjauan literatur (library research).

\section{PEMBAHASAN}

Tugas-tugas guru BK/konselor adalah untuk mendukung perkembangan pribadi dari para pelajar sesuai dengan kebutuhan, bakat, minat dan kepribadian mereka, khususnya untuk membantu peserta didik memahami dan mengevaluasi informasi dunia kerja dan membuat pilihan-pilihan terkait pekerjaan.

Berbagai jenis layanan dan kegiatan pendukung perlu dilakukan sebagai wujud nyata penyelenggaraan pelayanan bimbingan dan konseling terhadap sasaran layanan, yaitu peserta

didik (klien). Ada sejumlah layanan dan kegiatan pendukung dalam bimbingan dan konseling di sekolah.

Jenis-jenis layanan konseling meliputi: layanan orientasi, layanan informasi, layanan penempatan dan penyaluran, layanan penguasaan konten, layanan konseling perorangan, layanan bimbingan kelompok, layanan konseling kelompok, layanan konsultasi, layanan mediasi dan layanan advokasi (Prayitno, 2012:2-3).

Sebagian layanan konseling sudah dijelaskan pada artikel sebelumnya. Berikut ini akan dijelaskan lanjutan jenis layanan bimbingan dan konseling. 


\section{A. Layanan Bimbingan Kelompok}

Layanan bimbingan kelompok, adalah layanan konseling dalam rangka membantu sejumlah siswa secara bersama-sama memperoleh berbagai bahan dari narasumber yang berguna untuk menunjang kehidupannya, baik sebagai individu maupun sebagai pelajar untuk dapat menyesuaikan diri dalam suasana kelompok, menerima secara terbuka persamaan dan perbedaan antar anggota kelompok.

Tujuan Layanan bimbingan kelompok (Prayitno, dkk. 2004.) agar peserta didik dapat memperoleh bahan dan membahas pokok bahasan (topik) tertentu untuk menunjang pemahaman dan pengembangan kemampuan sosial, serta untuk pengambilan keputusan atau tindakan tertentu melalui dinamika kelompok. Layanan Bimbingan Kelompok berfungsi untuk pemahaman dan Pengembangan.

Layanan bimbingan kelompok ini dapat dilakukan melalui dinamika kelompok, di mana guru Bimbingan dan Konseling dapat memberikan satu buah kasus yang sedang "tren" di masyarakat untuk didiskusikan, misalnya mengenai bullying, siswadapat mendiskusikannya dan memaparkan hasil serta kesimpulannya tentang pelajaran yang dapat diambil dari kasus tersebut, sehingga siswa mendapatkan pembimbingan apa yang harus dilakukan dan apa yang tidak boleh dilakukan apabila menemukan hal serupa dalam kehidupan sehari-hari.

Materi layanan bimbingan kelompok, meliputi :

1. Pengenalan sikap, kebiasaan, bakat, minat dan cita-cita, serta penyalurannya.

2. Pengenalan kelemahan diri dan penanggulangannya, kekuatan diri dan pengembangannya.

3. Pengembangan kemampuan berkomunikasi, menerima/menyampaikan pendapat, bertingkah laku dan hubungan sosial, baik di runah, sekolah maupun di masyarakat, teman sebaya di sekolah dan luar sekolah, serta kondisi/peraturan sekolah.

4. Pengembangan sikap dan kebiasaan belajar yang baik di sekolah dan di rumah sesuai dengan kemampuan pribadi siswa.

5. Pengembangan teknik-teknik penguasaan ilmu pengetahuan, teknologi dan kesenian sesuai dengan kondisi fisik, sosial, dan budaya. 
6. Orientasi dan infornasi karier, dunia kerja, serta upaya memperoleh penghasilan.

7. Orientasi dan informasi perguruan tinggi sesuai dengan karier yang hendak dikembangkan.

8. Pengambilan keputusan dan perencanaan masa depan.

Layanan bimbingan kelompok mempunyai 3 fungsi, yaitu (Sukardi,Dewa Ketut: 2010.) :

1. Berfungsi informatif

2. Berfungsi pengembangan

3. Berfungsi preventif dan kreatif

Pelaksanaan kegiatan layanan bimbingan kelompok dapat dilaksanakan melalui kegiatan home room yang berfungsi untuk penyampaian informatif dan pengembangan, psikodrama yang berfungsi untuk keperluan terapi untuk masalahmasalah psikologis, serta sosiodrama yang berfungsi untuk keperluan terapi bagi masalah-masalah konflik sosial.

B. Layanan Konseling Kelompok

Layanan konseling kelompok, adalah layanan bimbingan dan konseling dalam rangka membantu siswa secara bersama-sama membahas dan mengentaskan masalah yang dialami masing-masing anggota kelompok.

Layanan konseling kelompok merupakan layanan yang diberikan guna mengentaskan masalah-masalah yang indentik yang dialami oleh beberapa siswa, sehingga melalui layanan konseling kelompok ini dengan bantuan konselor, peserta didik yang mengalami masalah yang sama tersebut dapat saling memberikan masukan untuk memperoleh jalan keluar atau solusi.

Tujuan konseling kelompok meliputi :

1. Melatih anggota kelompok agar berani berbicara dengan orang banyak. 
2. Melatih anggota kelompok agar dapat bertenggang rasa terhadap teman sebayanya.

3. Mengembangkan bakat dan minat masing-masing anggota kelompok.

4. Mengentaskan permasalahan kelompok.

Materi layanan kelompok mencakup :

1. Pemahaman dan pengembangan sikap, kebiasaan, bakat minat dan penyaluran.

2. Pemahaman kelemahan diri dan penanggulangannya, pengenalan kekuatan diri dan pengembangannya.

3. Mengembangkan kemampuan berkomunikasi, menyampaikan pendapat, bertingkah laku dan sosial yang baik di rumah, sekolah, maupun masyarakat.

4. Mengembangkan hubungan teman sebaya yang baik.

5. Mengembangkan sikap dan kebiasaan belajar, disiplin belajar yang baik.

6. Orientasi dan informasi karir, dunia kerja dan prospek masa depan.

\section{Layanan Konsultasi}

Layanan Konsultasi (Prayitno, dkk. 2004.) adalah sebagai suatu proses penyediaan bantuan teknis untuk konselor, orang tua, administrator dan konselor lainnya dalam mengidentifikasi dan memperbaiki masalah yang membatasi efektivitas peserta didik atau sekolah. konseling atau psikoterapi sebab konsultasi tidak merupakan layanan yang langsung ditujukan kepada klien, tetapi secara tidak langsung melayani klien melalui bantuan yang diberikan orang lain.

Layanan konsultasi adalah layanan konseling yang dilaksanakan oleh konselor terhadap konsulti yang memungkinkan konsulti memperoleh wawasan, pemahaman dan cara-cara yang perlu dilaksanakannya dalam menangani kondisi dan/atau permasalahan pihak ketiga.

Layanan ini bertujuan agar konsulti dengan kemampuannya sendiri dapat menangani kondisi dan permasalahan yang dialami pihak ke tiga. Dalam hal ini pihak ketiga mempunyai hubungan yang cukup berarti dengan konsulti, sehingga 
permasalahan yang dialami pihak ketiga itu sebahagian menjadi tanggung jawab konsulti.

D. Layanan Mediasi

Layanan mediasi berarti kegiatan yang mengantarai atau menghubungkan dua hal yang semula terpisah; menjalin hubungan antara dua kondisi yang berbeda, serta mengadakan kontak, sehingga dua yang semula tidak sama menjadi saling terkait

Layanan mediasi merupakan layanan konseling yang di laksanakan konselor terhadap dua pihak atau lebih yang sedang dalam keadaan saling tidak menemukan kecocokan. Dengan layanan mediasi konselor berusaha mengantarai dan membangun hunbungan di antara mereka, sehingga mereka menghentikan dan terhindar dari pertentangan lebih lanjut yang merugikan sesama pihak.

Berbeda dengan layanan yang lain terutama layanan konseling perorangan, dalam layanan mediasi, konselor menghadapi klien yang terdiri atas dua pihak atau lebih.

Tujuan dari layanan mediasi ialah agar tercapainya kondisi hubungan yang positif dan kondusif diantara para klien atau pihak-pihak yang bertikai atau bermusuhan. Selain itu agar terjadi perubahan atas kondisi awal yang negatif menjadi kondisi baru dalam hubungan antara kedua belah pihak yang bermasalah.

\section{E. Layanan Advokasi}

Layanan Advokasi yaitu layanan yang membantu agar hak-hak keberadaan, kehidupan dan perkembangan individual yang bersangkutan kembali diperoleh setelah hak-hak tersebut selama ini dirampas, dihalangi dan dibatasi.

Tujuan layanan advokasi secara umum yaitu mengentaskan klien dari suasana yang buruk di dirinya, sedangkan tujuan secara khusus yaitu membebaskan klien dari cengkraman pihak tertentu.

Komponen layanan advokasi yaitu :

1. Konselor 
2. Korban penyelenggaraan hak

3. Pihak-pihak terkait

Materi layanan advokasi yaitu :

1. Terfokus pada klien yang terkena perlakuan negatif dari pihak-pihak tertentu dan merugikan klien

2. Berkenaan dengan materi karakter

\section{PENUTUP}

Guru Bimbingan dan Konseling di sekolah harus memiiki kecakapan untuk melaksanakan layanan dengan maksimal, sehingga pelayanan bantuan untuk peserta didik, baik secara perorangan maupun kelompok, agar mampu mandiri dan berkembang secara optimal, dalam bidang bimbingan belajar dan bimbingan karir, melalui berbagai jenis kegiatan pendukung, berdasarkan norma-norma yang berlaku.

\section{REFERENSI}

Awlawi, Addahri Hafidz.2013. "Teknik Bermain Peran Pada Layanan Bimbingan Kelompok untuk Meningkatkan Self-Esteem”. Jurnal Ilmiah Konseling, Vol.2, No.1.

Azizah, Nur.2019. "Layanan Konseling Berbasis Komunitas Bagi Klien di Balai Rehabilitasi Sosial”. Jurnal Dakwah dan Komunikasi, Vol.13, No.1.

Sari, Putri Hervita, Firman, Syahniar.2016. "Efektivitas Layanan Bimbingan Kelompok dalam Meningkatkan Asertivitas Siswa”. Jurnal Ilmiah Konseling, Vol.2, No.3. 